\title{
Research priorities for advancing adoption of cover crops in agriculture-intensive regions
}

\author{
Sarah Carlson, ${ }^{a}$ Practical Farmers of Iowa \\ Ryan Stockwell, ${ }^{\mathrm{b}} *$ National Wildlife Federation
}

Submitted July 9, 2013 / Revised August 28, 2013 / Published online August 29, 2013

Citation: Carlson, S., \& Stockwell, R. (2013). Research priorities for advancing adoption of cover crops in agriculture-intensive regions. Journal of Agriculture, Food Systems, and Community Development, 3(4), 125-129. http://dx.doi.org/10.5304/jafscd.2013.034.017

Copyright (C) 2013 by New Leaf Associates, Inc.

\begin{abstract}
Given certain ecologic and agronomic characteristics of conventional corn and soybean monocultures, cropping systems reliant solely on these two commodities inevitably lose soil and nutrients. Leaky cropping systems not only hamper society with negative externalities, but also erode the very natural resources needed to produce food and sustain civilization. The United States Department of Agriculture (USDA), state agriculture department staff, farmer organizations, agribusiness leaders, and conservation and environmental organizations now see cover crops as a solution to reduce the negative externalities of conventional row-crop agriculture. Farmers are asking for increased agronomic and economic research to
\end{abstract}

\footnotetext{
${ }^{a}$ Midwest Cover Crop Research Coordinator, Practical Farmers of Iowa; sarah@practicalfarmers.org

b,* Corresponding author: Ryan Stockwell, Agriculture Program Manager, National Wildlife Federation; N2761 Wren Drive, Medford, Wisconsin 54451 USA; +1-715-965-2538; stockwellr@,nwf.org
}

help them understand the benefits of and implement the use of cover crops. Researchers for the most part are not keeping up with farmers' innovations on cover crops nor on providing the information sought by farmers. This article outlines the questions farmers are asking about cover crops and provides suggestions to agronomists, soil scientists, and researchers on research topics to best answer those questions. Additionally, social scientists must initiate a new round of research to understand the underlying concerns farmers have with cover crops and help to define the information (both content and source) that best informs and influences farmers. This article outlines specific issues and questions social scientists can research to contribute to the advancement of more sustainable farming practices and, in particular, cover crops.

\section{Keywords}

adoption, climate change, cover crops, diversity, externalities, innovation, natural resources, nutrient loss, resilience 
G iven certain ecologic and agronomic characteristics of conventional corn and soybean monocultures, cropping systems reliant solely on these two commodities inevitably lose soil and nutrients. Leaky cropping systems not only hamper society with negative externalities, but also erode the very natural resources needed to produce nutrious food and sustain civilization. As David Montgomery points out in Dirt: The Erosion of Civilizations, "our soil is the root of our existence, supporting our feet, our farms, our cities"

(Montgomery, 2012, p. 2). Food systems with heavy reliance on these intensive monocultures or two-crop systems face increased threat of instibility in commodity supply while contributing to the externalities associated with these systems.

Moreover, farmers responding to the economic pressures of the protein-industrial complex continue to intensify commodity production. This biologically weak system is now being replicated globally at the exact time that climate change has intensified weather, resulting in unpredictable extremes. The results of this perfect storm are numerous hypoxic zones in the world's bays and gulfs adjacent to the mouths of rivers (Middleburg \& Levin, 2009; Scientific and Technical Advisory Panel (STAP), 2011), increased flooding followed by drought conditions and tons of soil silting in lakes and waterways (Heathcote, Filstrup, \& Downing, 2013), and the resiliency of food systems put into question. Rivers not only transport commodities to the world's food systems, but also unintentionally transport nitrogen, phosphorus, and sediment.

The three categories of non-point source pollutants to the U.S. Mississippi River Basin are sediment, nutrients, and pesticides. Over the past 150 years, farmers have converted more than 60 percent of the basin's land to annual cropland. Upper Midwest farmers currently manage 87 million acres (35.2 million hectares) of annual row crops. Unfortunately, the types of crops that dominate this landscape are "leaky" due to their relatively short growing season, narrow rooting zone compared to an assemblage of diverse plant types, and percentage of the soil left bare throughout the calendar year. From 1985to 2005, nitrogen loads to the Gulf of Mexico ranged from 893,000 to
2,436,000 tons $(810,000-2,210,000$ metric tons) and phosphorus loads ranged from 88,956 to 198,400 tons (80,700-180,000 metric tons) per year (Mississippi River/Gulf of Mexico Watershed Nutrient Task Force, 2008)(Hypoxia Task Force, 2008). Of those from corn and soybeans, an average of 52 percent of the total nitrogen and 25 percent of the total phosphorus came from the Upper Mississippi sub-basin (Mississippi River/Gulf of Mexico Watershed Nutrient Task Force, 2008).

To combat this loss of nutrients and soil, the Environmental Protection Agency mandated that states in the basin write a strategy to reduce both point and non-point source pollution. Two states have written strategies in response to this charge. The Iowa Department of Agriculture and Land Stewardship, in cooperation with Iowa State University and the Iowa Department of Natural Resources, recently released Iowa's Nutrient Reduction Strategy. This strategy includes a thorough non-point source scientific assessment about individual farm practices and their affects on the reduction of nitrogen or phosphorus loading of the Mississippi River. The one practice that stands out, which decreases both nitrogen and phosphorus loss while cost-effectively maintaining a productive cash crop farming system is cover cropping, growing crops for the protection and enrichment of the soil. Although reductions in tillage, improved nutrient application timing, and edge-of-field practices like grassed waterways or bioreactors are effective at reducing nutrient losses, none provides the similar significant reductions in nutrient loading like cover crops. Most encouragingly, with the right management, cover crops can easily be added to a large percentage of the 174.4 million acres (70.6 million hectares) of corn and soybeans predicted to be planted in the U.S. in 2013 without major changes to the current production paradigm. Due to all these factors, cover crops have been seen as the obvious next step for on-farm conservation. Yet there is much to learn in order to ensure farmers are successful with cover crops; getting over the learning curve and social resistance to change are important to promoting widespread adoption (Rogers, 2003)(Rogers, 2003). 
The USDA, state agriculture department staff, farmer organizations, agribusiness leaders, and conservation and environmental organizations now see cover crops as a solution to reduce the negative externalities of conventional row-crop agriculture while improving the resiliancy of food systems to challenges associated with climate change. Significant funding from these organizations has helped jump-start a hot trend among mainstream farmers. However, universities, especially the land grant universities in the Mississippi River Basin who are most able to initiate rigourous research, have been unable to keep up with farmer-led, on-farm innovation. Farmers are asking for increased agronomic and economic research to help them understand the benefits of and implement the use of cover crops (see table 1).

Early, albeit limited, scientific research by agronomists has shown that cover crops are an economic benefit to farmers. Miguez and Bollero found that across all regions of the U.S., compared to no cover crop, corn yield increased 24 percent following a legume cover crop and decreased by 1 percent following a winter rye cover crop (Miguez \& Bollero, 2005). Although the difference within the winter rye data of the Miguez and Bollero meta-analysis was not statistically significant, more recent studies have shown a 6 percent reduction in corn yield following a winter rye cover crop. However, the total number of years using a winter cover crop on research plots varies. Few studies use farms that have a long history of cover-crop usage. A high percent of research about cover crops is focused on a single species' effect on yield performance, water use, soil organic matter, available water content, total carbon and total nitrogen, grazing potential, water quality, and other indicators of performance. Moreover, many such studies implement practices designed to maximize covercrop growth or control planting or termination dates rather than implement practices commonly used on farms to maximize commodity crop yields.

Few, if any, studies estimate potential diverse cover-crop mix effect on environmental and yield performance indicators. Cover-crop species selection for mixes specific to regions have been done on a very limited basis. Additionally, the majority of published studies drill cover crops following harvest or termination of a cash crop. Most farmers in the Upper Mississippi basin use

\section{Table 1. Cover-Crop Research Questions Sought by Farmers}

\begin{tabular}{|c|c|}
\hline Farmers' practical questions & Question to be studied by researchers \\
\hline Economic analysis/cost benefit & $\begin{array}{l}\text { What are the short-term ( }>3 \text { years), medium term }(3-6 \text { years), and long-term ( } 6+ \\
\text { years) returns on the investment of cover crops to the soil, farm business, } \\
\text { community, rural retailers, service sector, other farm businesses, etc.? }\end{array}$ \\
\hline Seeding methods & $\begin{array}{l}\text { What is the success of cover crops planted at four or five different times during } \\
\text { the year: early spring; V-5/side-dress; pre-tassle; black-layer; post-harvest? What } \\
\text { are the various machinery options and which are most efficient at acres/hour? }\end{array}$ \\
\hline Scaling up cover crop seed production & $\begin{array}{l}\text { How can lessons from food value chains be applied to cover-crop seed } \\
\text { production? }\end{array}$ \\
\hline Effect on cash crop yield & What long-term effects does a cover crop have on cash-crop yield? \\
\hline Performance of cover crop mixes & $\begin{array}{l}\text { Which cover crop species are most appropriate for each state? Which species } \\
\text { belong in a cover crop mix? }\end{array}$ \\
\hline Environmental impacts of cover crops & $\begin{array}{l}\text { How do cover crops impact water quality at the HUC-12 or HUC-8 watershed } \\
\text { scale? How does that impact small- and mid-sized water utilities? }\end{array}$ \\
\hline $\begin{array}{l}\text { Breeding for specific cover-crop } \\
\text { performance }\end{array}$ & $\begin{array}{l}\text { How can cash-crop and cover-crop breeding be synchronized for improved } \\
\text { performance? }\end{array}$ \\
\hline $\begin{array}{l}\text { Nutrient release syncronization with } \\
\text { cash-crop needs }\end{array}$ & $\begin{array}{l}\text { What species provide cash-crop-specific nutrients at the correct physiological } \\
\text { time? }\end{array}$ \\
\hline
\end{tabular}


Table 2. Sociological and Psychological Research Needed To Advance Cover-Crop Adoption

\begin{tabular}{ll}
\hline Cover crop diffusion issues & Questions to be studied \\
\hline $\begin{array}{l}\text { Information on cover crops and } \\
\text { associated practices }\end{array}$ & - What is the best format for delivering information on cover crops and \\
& $\begin{array}{l}\text { associated practices to different agriculture stakeholder groups (farmers, } \\
\text { input service providers, ag. extension, ag. industry leaders)? } \\
\text { - }\end{array}$ \\
& Who is the best "expert" or messenger to deliver information to various \\
& stakeholder groups? \\
- Is there a particular order in which information should be provided? & Where and how should information be included on problems with existing \\
& practices?
\end{tabular}

\begin{tabular}{ll}
\hline $\begin{array}{l}\text { Commonly held assumptions or myths } \\
\text { about agriculture that inhibit cover- } \\
\text { crop adoption }\end{array}$ & $\begin{array}{l}\text { What is the best method to counter or disable assumptions that cover crops } \\
\text { inhibit commodity crops, make fields too wet or dry, rob nutrients, etc.? }\end{array}$ \\
\hline $\begin{array}{l}\text { Sociological aspects directly (peer } \\
\text { pressure) inhibiting or encouraging } \\
\text { cover-crop adoption }\end{array}$ & $\begin{array}{l}\text { How does peer pressure occur in agricultural communities? Among various } \\
\text { stakeholder groups? } \\
\text { How can cover-crop leaders disable negative pressure and enable positive } \\
\text { pressure? }\end{array}$ \\
\hline $\begin{array}{ll}\text { Psychological aspects inhibiting or } \\
\text { encouraging cover-crop adoption }\end{array}$ & $\begin{array}{l}\text { What are simple and observable indicators of farmers' risk tolerance and interest } \\
\text { in innovating? }\end{array}$ \\
\hline $\begin{array}{l}\text { Disabling cultural concepts impacting } \\
\text { cover-crop adoption }\end{array}$ & $\begin{array}{l}\text { How can the long-held beliefs that a heavily tilled field is a "clean" field, or the } \\
\text { view that anything growing that is not the commodity crop is a "weed" be } \\
\text { changed? }\end{array}$ \\
\hline
\end{tabular}

airplanes or ground equipment to over-seed into a standing cash crop. Few studies deal with the issues of establishment prior to determining performance indicators on yield and environmental benefit. While these questions persist, innovative farmers are forging ahead with cover crops, experiencing general success. Yet the majority of farmers will refrain from or delay adopting cover crops predominantly out of their own uncertainty with new practices and human nature, fearing change (Singer, Nusser, \& Alf, 2007).

In one of the few surveys of its kind, Singer and collegues in 2005 surveyed farmers across the Upper Mississippi region about their adoption and use of cover crops showing a small adoption rate for cover crops. Social scientists must initiate a new round of psychological and sociological research to understand the underlying concerns farmers have with adopting the use of cover crops. Additionally, behavior research can help to define the source and content of information that best informs and influences farmers. Research on the diffusion of innovation exists, based on older technologies and different socio-economic contexts. The seminal work, Diffusion of Innovations by Everett Rogers, is currently in its fifth edition and was originally published in 1962. Further research into farmer adoption and innovation is needed to develop the tools and information necessary to simplify and quicken the inclusion of more cover crops in agricultureintensive regions (see table 2) and particularly in a new socio-economic context. The diffusion of innovation occurs at different speeds and has different successes for different technologies in specific socio-economic conditions. Wide and farreaching socio-economic aspects will have varying impacts on the diffusion of different innovations. Moreover, diffusion of innovation depends heavily on the communication of specific methods by particular actors.

By providing this analysis that marries the agronomic production questions with the socioeconomic, cultural, psychological, and sociological aspects of the diffusion of innovation of cover crops, researchers will provide valuable information and guidance to individuals and organizations working to reduce the natural-resource degredation of agriculture. Such information will prove valuable in speeding up the diffusion process and improving success with cover crops. Increased cover-crop 
adoption will reduce negative externalities associated with dominant monoculture cropping systems while improving the resiliancy of food systems to adverse weather, changing pest and weed challenges, and other production difficulties associated with a changing climate.

\section{References}

Heathcote, A. J., Filstrup, C. T., \& Downing, J. A. (2013). Watershed sediment losses to lakes accelerating despite agricultural soil conservation efforts. Plos ONE, 8(1), e53554. http://dx.doi.org/10.1371/journal.pone.0053554

Middleburg, J. J., \& Levin, L. A. (2009). Coastal hypoxia and sediment biogeochemistry. Biogeosciences Discussions, 6, 3655-3706. http://dx.doi.org/10.5194/bgd-6-3655-2009

Miguez, F. E., \& Bollero, G. A. (2005). Review of corn yield response under winter cover cropping systems using meta-analytic methods. Crop Science, 45(6), 2318-2329. http://dx.doi.org/10.2135/cropsci2005.0014

Mississippi River/Gulf of Mexico Watershed Nutrient Task Force. (2008). Gulf bypoxia action plan 2008 for reducing, mitigating, and controlling bypoxia in the northern Gulf of Mexico and improving water quality in the Mississippi River Basin. Washington, D.C.: Author. Retrieved from http://water.epa.gov/type/ watersheds/named $/ \mathrm{msbasin} /$ actionplan.cfm\# documents

Montgomery, D. R. (2012). Dirt: The erosion of civilizations. Berkeley and Los Angeles: University of California Press.

Rogers, E. M. (2003). Diffusion of innovations (Fifth Ed.). New York: The Free Press.

Scientific and Technical Advisory Panel [STAP]. (2011). Hypoxia and nutrient reduction in the coastal zone: Advice for prevention, remediation and research (STAP advisory document). Washington, D.C.: Global Environment Facility. Retrieved from http://www.thegef.org/gef/sites/thegef.org/files/ publication/STAP Hypoxia low.pdf

Singer, J. W., Nusser, S. M., \& Alf, C. J. (2007). Are cover crops being used in the US Corn Belt? Journal of Soil and Water Conservation, 62(5), 353-358.

Retrieved from http://www.jswconline.org 